International Journal of Cancer

\title{
Comparative risk assessment of carcinogens in alcoholic beverages using the margin of exposure approach
}

\begin{tabular}{|r|l|}
\hline Journal: & International Journal of Cancer \\
\hline Manuscript ID: & IJC-12-0008 \\
\hline Wiley - Manuscript type: & Epidemiology \\
\hline Author: & 03-Jan-2012 \\
\hline Complete List of Authors: & $\begin{array}{l}\text { Lachenmeier, Dirk; Technische Universität Dresden, Epidemiological } \\
\text { Research Unit, Institute for Clinical Psychology and Psychotherapy; } \\
\text { CVUA Karlsruhe, } \\
\text { Przybylski, Maria C.; CVUA Karlsruhe, } \\
\text { Rehm, Jürgen; Centre for Addiction and Mental Health (CAMH), } \\
\text { Social and Epidemiological Research Department }\end{array}$ \\
\hline Key Words: & $\begin{array}{l}\text { alcoholic beverages, risk assessment, dose-response relationship, } \\
\text { margin of exposure, epidemiology }\end{array}$ \\
\hline &
\end{tabular}




\section{Comparative risk assessment of carcinogens in alcoholic beverages using the}

\section{2 margin of exposure approach}

3 Dirk W Lachenmeier, ${ }^{1,2^{*}}$ Maria C Przybylski ${ }^{2}$, and Jürgen Rehm ${ }^{1,3,4}$

$4{ }^{1}$ Epidemiological Research Unit, Institute for Clinical Psychology and Psychotherapy, Technische

5 Universität Dresden, Dresden, Germany

$6 \quad{ }^{2}$ Chemisches und Veterinäruntersuchungsamt (CVUA) Karlsruhe, Karlsruhe, Germany

$7 \quad{ }^{3}$ Social and Epidemiological Research Department, Centre for Addiction and Mental Health (CAMH),

8 Toronto, Canada

$9{ }^{4}$ Dalla Lana School of Public Health, University of Toronto, Toronto, Canada

10 * Corresponding author. Chemisches und Veterinäruntersuchungsamt (CVUA) Karlsruhe, Weissenburger

11 Strasse 3, D-76187 Karlsruhe, Germany. Fax: +49-721-926-3549. E-mail: Lachenmeier@ web.de

13 Short title: Comparative risk assessment of carcinogens in alcoholic beverages

14 Key words: Alcoholic beverages, risk assessment, dose-response relationship, margin of exposure,

15 epidemiology

16 Article category: Research Article; Epidemiology

18 Brief statement about novelty and impact:

19 This study is the first to apply a quantitative approach for comparative risk assessment of different 20 carcinogens in alcoholic beverages. Ethanol was found to be the most important ingredient leading to 21 substantial cancer risk. This result clarifies misinformation that other contaminants are predominantly 22 responsible for the carcinogenicity, e.g., claims by industry about carcinogenic contaminants, which are 23 not contained in certain brand products. Until now, the scientific basis was lacking to refute such 24 misleading advertisement claims. The developed methodology can also be transferred to other ingredients 25 or to comparative risk assessment of other substances. 


\section{Abstract}

27 Alcoholic beverages have been classified as carcinogenic to humans. As alcoholic beverages are 28 multi-component mixtures containing several carcinogenic compounds, a quantitative approach is 29 necessary to compare the risks.

30 Fifteen carcinogenic compounds (acetaldehyde, acrylamide, aflatoxins, arsenic, benzene, 31 cadmium, ethanol, ethyl carbamate, formaldehyde, furan, lead, 4-methylimidazole, $N$ 32 nitrosodimethylamine, ochratoxin A, and safrole) occurring in alcoholic beverages were 33 identified based on monograph reviews by the International Agency for Research on Cancer. The 34 margin of exposure (MOE) approach was used for comparative risk assessment. MOEs were 35 calculated for different drinking scenarios (low risk and heavy drinking) and different levels of 36 contamination for four beverage groups (beer, wine, spirits, unrecorded alcohol).

37 The lowest MOEs were found for ethanol (3.1 for low risk and 0.8 for heavy drinking). Lead and 38 arsenic have average MOEs between 10 and 300, followed by acetaldehyde, cadmium and ethyl 39 carbamate between 1,000 and 10,000. All other compounds had average MOEs above 10,000 40 independent of beverage type.

41 Ethanol was identified as the important carcinogen in alcoholic beverages, with a clear dose42 response curve. Some other compounds (lead, arsenic, ethyl carbamate, acetaldehyde) may pose 43 risks below thresholds normally tolerated for food contaminants, but from a cost-effectiveness 44 point of view, the focus should be on reducing alcohol consumption in general than on mitigative 45 measures for some contaminants that contribute only in minor fashion (if at all) to the total health 46 risk. 


\section{Introduction}

48 Since the first observation in France in the beginning of the last century that the consumption of

49 absinthe was related to oesophageal cancer, ${ }^{1}$ epidemiology has established a causal relationship

50 between alcohol consumption in general (i.e. independent of beverage type) and the occurrence 51 of cancer. Moreover, in 1988, the International Agency for Research on Cancer (IARC) classified

52 alcoholic beverages into group 1 as "carcinogenic to humans". ${ }^{2}$ At this time, a causal relationship 53 between alcohol consumption and the occurrence of malignant tumours of the oral cavity, 54 pharynx, larynx, oesophagus and liver was established. In the following IARC evaluations, colo55 rectum cancer and female breast cancer were added to the list of cancer sites with causal 56 relationship, while only limited evidence points to stomach and pancreas as further sites. ${ }^{3-5}$

57 While the epidemiological evidence on the carcinogenicity of alcoholic beverages had been 58 sufficiently established for several decades, the principal mechanism underlying this relationship 59 has been a matter of debate. For a long time it was assumed that ethanol itself was not a direct 60 carcinogen. The 1988 IARC monograph, for example, stated that there is inadequate evidence for 61 the carcinogenicity of ethanol in experimental animals. ${ }^{2}$ However, this statement was based on 62 lack of well-controlled and designed experimental studies rather than on a clear absence of effect. 63 Since then, two adequately designed long-term animal studies have clearly demonstrated that 64 ethanol causes dose-related cancer in mice and rats at sites similar to those observed in humans 65 (liver and oral cavity). ${ }^{6,7}$ As a result of this new evidence, the 2007 IARC evaluation concluded 66 that there is sufficient evidence in experimental animals for the carcinogenicity of ethanol.,

67 Furthermore, substantial mechanistic evidence has become available in humans who are deficient 68 in aldehyde dehydrogenase that acetaldehyde derived from the metabolism of ethanol in alcoholic 69 beverages contributes to the causation of malignant oesophageal tumours. Acetaldehyde reacts 
Comparative risk assessment of carcinogens in alcoholic beverages

70 with DNA to form various DNA adducts, and elevated levels of acetaldehyde-derived DNA

71 adducts have been detected in white blood cells of individuals who are heavy alcoholic beverage

72 drinkers. Some of the DNA adducts that are increased after alcoholic beverage consumption are

73 mutagenic in human cells. In addition, these adducts can undergo rearrangements in double-

74 stranded DNA, which can result in the formation of DNA-protein cross-links and DNA

75 interstrand cross-links, which are mechanistically consistent with the generation of chromosomal

76 aberrations. Elevated levels of chromosomal aberrations have been observed in human cells in

77 culture after exposure to acetaldehyde as well as in vivo in human alcoholics. ${ }^{3}$ This mechanistic

78 evidence combined with the results in experimental animals and the epidemiological observation

79 that all alcoholic beverages cause cancer demonstrate that ethanol is an important carcinogenic

80 compound in alcoholic beverages. In their most recent evaluation, IARC has therefore classified

81 both "ethanol in alcoholic beverages" as well as "acetaldehyde associated with alcohol

82 consumption" into group 1 as "human carcinogens". 4

83 Nevertheless, misinformation is still spread that ethanol is not a carcinogen at all or that alcohol-

84 related cancer is exclusively caused by something else. For example, promotional material on an

85 ethanol-containing mouthwash states that "ethanol is not a carcinogen; however, alcoholic

86 beverages contain numerous carcinogenic compounds such as urethane, nitrosamines, polycyclic

87 hydrocarbons and aflatoxins". ${ }^{8}$ While there is certainly ample evidence pointing to the fact that

88 ethanol is the major carcinogenic compound in alcoholic beverages, the assumption about other

89 carcinogens cannot be directly negated. Alcoholic beverages are multi compound mixtures and

90 (similar to tobacco) may regularly contain various carcinogens such as those mentioned in the

91 promotional material. The IARC also remarked that identification of ethanol as a known

92 carcinogenic agent in alcoholic beverages does not rule out the possibility that other components

93 may also contribute to their carcinogenicity. ${ }^{3}$ A summary of carcinogens typically occurring in 
94 alcoholic beverages is provided in table 1. In fact some of these carcinogens in alcoholic 95 beverages, and specifically ethyl carbamate (urethane), are seen by international bodies such as 96 the Joint FAO/WHO Expert Committee on Food Additives (JECFA) or the European Food 97 Safety Authority (EFSA) as public health risk independent of ethanol. ${ }^{9,10}$ For this reason, the 98 European Commission has advised the member states to monitor the ethyl carbamate 99 contamination in certain alcoholic beverages. ${ }^{11}$ Another example is $N$-nitrosodimethylamine 100 (NDMA), which was first found in German beers in $1978,{ }^{12}$ when concentrations of up to $10168 \mu \mathrm{g} / \mathrm{L}$ caused worldwide concern. A change in the target organ specificity of NDMA by co102 administration of ethanol was observed: when NDMA was given in combination with ethanol, 103 rats and mice developed tumours in the nasal cavity, which is not a target site for this 104 nitrosamine. This suggests that ethanol may influence the initiation of carcinogenesis in some 105 manner, but it is also possible that the process is enhanced due to some mechanistic events: the 106 facilitation of entry into the target cell by ethanol, a change in intracellular metabolism or 107 suppression of DNA repair. The hypothesis of competitive inhibition of hepatic metabolism of 108 the carcinogen, which allows it to reach the target organs, has also been proposed. ${ }^{3}$ The questions 109 about the risk posed by other substances other than ethanol is especially important for unrecorded 110 (i.e. illicitly or home-produced) alcohol, which is assumed to potentially contain higher 111 concentrations of contaminants, especially ethyl carbamate and acetaldehyde. ${ }^{13,14}$

112 The literature currently offers no quantitative information if and how much other carcinogenic 113 constituents or contaminants of alcoholic beverages compare with and contribute to the risk 114 generated by ethanol. Such information is necessary especially to inform risk management to 115 prioritize cancer prevention.

116 Several approaches were suggested in the past for quantitative risk assessment of carcinogens. ${ }^{15}$ 117 From these, the so-called margin of exposure (MOE) approach is currently preferred by 
Comparative risk assessment of carcinogens in alcoholic beverages

118 international bodies such as $\mathrm{WHO}^{16}$ or $\mathrm{EFSA}^{17}$, for recent review see Benford et al. ${ }^{18}$. This study

119 will therefore apply the MOE approach to provide a comparative risk assessment of carcinogens

120 occurring in alcoholic beverages. The results will be used to point out options for alcohol policy.

\section{Methods}

122 The selection of carcinogens and their occurrence in alcoholic beverages was based on the most 123 recent detailed IARC review, ${ }^{3}$ for exceptions see remarks in results section. The assessment of 124 toxicological endpoints and benchmark doses (BMD) for the selected carcinogens was generally 125 based on literature data, as own dose-response modelling would have gone beyond the scope of 126 this study. Suitable risk assessment studies including endpoints and dose-response modelling 127 results were typically identified in monographs of national and international risk assessments 128 bodies such as WHO International Programme on Chemical Safety (IPCS), JECFA, US 129 Environmental Protection Agency (EPA) and EFSA. For substances without available 130 monographs or with missing data on dose-response modelling results, the scientific literature in 131 general was searched for such data. Searches were carried out in September 2011 in the following 132 databases: PubMed (U.S. National Library of Medicine, Bethesda, MD), Web of Science 133 (Thomson Reuters, Philadelphia, PA), Scopus (Elsevier B.V., Amsterdam, the Netherlands), and 134 Google Scholar (Google Inc., Mountain View, CA).

135 The BMD/MOE approach was used for risk assessment. ${ }^{17,19,20}$ Based on dose-response 136 modelling, the BMD is the point on the dose response curve, which characterizes adverse effects.

137 This value can then be used in combination with exposure data to calculate a MOE for 138 quantitative risk assessment. The MOE is defined as the ratio between the lower one-sided 139 confidence limit of the BMD (BMDL) and estimated human intake of the same compound. It can 140 be used to compare the health risk of different compounds and in turn prioritize risk management 
Comparative risk assessment of carcinogens in alcoholic beverages

141 actions. By definition, the lower the MOE, the larger the risk for humans; generally a value under 14210,000 used to define public health risks. ${ }^{21}$

143 If BMDL values were unavailable in the literature, no observed effect level (NOEL) or no 144 observed adverse effect level (NOAEL) values were identified as surrogate thresholds instead. 145 The MOEs were then calculated by dividing the NO(A)EL by the estimated human intake.

146 For each beverage group (i.e. beer, wine, spirits and unrecorded alcohol), the human intakes were 147 calculated for two different drinking scenarios (low risk drinking and heavy drinking) based on 148 the drinking guidelines for Canada, which consider that $13.6 \mathrm{~g}$ pure alcohol constitute a standard 149 drink. $^{22}$ For both drinking scenarios, MOEs for average contamination as well as maximum 150 contamination with the different carcinogens were additionally calculated to estimate a range for 151 average and worst case contamination scenarios.

\section{Results}

153 Alcoholic beverages may contain more than 1,000 different components, ${ }^{2}$ from which several are 154 potentially carcinogenic. In the first step of the comparative risk assessment, a selection of 155 compounds for further evaluation has to occur. The IARC Monographs Working Group Vol. 96 ${ }^{3}$

156 compared the complete IARC list of carcinogens with the list of compounds regularly occurring 157 in alcoholic beverages (appendix 1 in the IARC 1988 monograph $^{2}$ ) and provided a summary of 158 carcinogens that may be present in alcoholic beverages (see table 1.14, p. 113 in the IARC 2010 159 monograph $^{3}$ ). From this summary, we have chosen the compounds set into IARC group 1 160 (carcinogenic to humans), IARC group 2A (probably carcinogenic to humans) and IARC group 161 2B (possibly carcinogenic to humans) to be included in our evaluation. Compounds set into 162 IARC group 3 (not classifiable as to its carcinogenicity to humans) such as deoxynivalenol, 
163 nivalenol, organolead compounds and patulin were excluded from our evaluation. The remaining 164 compounds in groups 1, 2A and 2B were acetaldehyde, acrylamide, aflatoxins, arsenic, benzene, 165 cadmium, ethanol, ethyl carbamate, furan, lead, NDMA, and ochratoxin A (Table 1). Since the 166 writing of the exposure section in the IARC Monograph Vol. 96 in 2007 (two of the authors of 167 this article, DWL and JR, were members of this working group and contributed to the initial 168 evaluation), additional evidence for some compounds has become available. For example, the 169 regular occurrence of formaldehyde, an IARC group 1 carcinogen, in alcoholic beverages was 170 detected. ${ }^{23}$ Furthermore, 4-methylimidazole a contaminant of caramel colours with known use in 171 certain alcoholic beverages, ${ }^{24,25}$ was newly evaluated by IARC in 2011 and set into group $2 \mathrm{~B} .{ }^{26}$ 172 Safrole, another group 2B substance, may also potentially occur in alcoholic beverages. ${ }^{27}$ Safrole 173 is a flavour compound with a comparably high ranking in the Berkeley carcinogenic potency 174 project due to its occurrence in spices. ${ }^{28}$ Therefore, formaldehyde, 4-methylimidazole and safrole 175 were added to our list (Table 1).

176 The data on occurrence of the chosen compounds in alcoholic beverages are summarized in Table 177 2. Data on recorded alcohol (i.e. commercial wine, beer and spirits) were predominantly based on 178 the summaries in the IARC 2010 monograph $^{3}$. In some instance, actualized data from 179 international surveys (e.g. from EFSA) were available (see details in Table $2^{29-33}$ ). Less data on 180 unrecorded alcohol is generally available. ${ }^{13,34}$ The data were therefore taken from an own survey 181 recently conducted in the European Union. ${ }^{14}$

182 In general, the contamination of alcoholic beverages with the selected compounds is subject to a 183 wide variation depending on product category, raw material, or diligence during manufacturing. 184 The substances typically occur at ppb-levels or below, e.g. for aflatoxins, cadmium, or ochratoxin 185 A. The exception are ethyl carbamate and formaldehyde, which may reach ppm-levels but only in 186 certain products, while acetaldehyde typically occurs in ppm-levels in all product categories 
Comparative risk assessment of carcinogens in alcoholic beverages

187 (besides vodka and neutral alcohol-based products), and may even exceed $1 \mathrm{~g} / \mathrm{L}$ in certain highly

188 contaminated products. No clear difference between commercial and unrecorded alcoholic

189 beverages was detected with the exception of lead that may exceed $1 \mathrm{mg} / \mathrm{L}$ in highly

190 contaminated unrecorded alcohol.

191 The toxicological endpoints used for dose-response modelling and the chosen points of departure

192 for MOE assessment are shown in Table 3., ${ }^{6,10,21,35-62}$ According to international guidelines for

193 risk assessment using the MOE approach, ${ }^{16-18,20}$ the most sensitive toxicological endpoint was

194 chosen, when several endpoints were available. For some agents such as formaldehyde, benzene

195 or lead, non-cancer endpoints were more sensitive than cancer endpoints or cancer endpoints

196 were unavailable. To provide a conservative assessment, we decided to use these non-cancer

197 endpoints in these cases. For a third of the compounds, human epidemiological data were

198 available suitable for dose-response modelling. For the rest of the compounds, the assessments

199 have to be based on animal data. The effective doses of the compounds as expressed by BMDL

200 vary over a very wide range, from $0.00087 \mathrm{mg} / \mathrm{kg}$ bw/day for aflatoxin $\mathrm{B}_{1}$ to $700 \mathrm{mg} / \mathrm{kg}$ bw/day 201 for ethanol.

202 Table 4 shows the corresponding MOEs for several scenarios and alcoholic beverage groups. An 203 average over all groups is provided in Figure 1. The lowest MOEs were calculated for ethanol, 204 with 3.1 for low risk drinking and 0.8 for heavy drinking. Lead and arsenic have average MOEs 205 between 10 and 300, followed by acetaldehyde, cadmium and ethyl carbamate between 1,000 and 206 10,000. Safrole, ochratoxin A, NDMA, 4-methylimidazole, furan, formaldehyde, aflatoxin B1 207 and acrylamide have average MOEs above 10,000, even in the heavy drinking scenario. 


\section{Discussion}

209 Our study provides the first comprehensive comparison of the risk related to compounds in

210 alcoholic beverages. It is interesting to note that from all evaluated agents, ethanol exhibits the

211 lowest potency in terms of BMDL in $\mathrm{mg} / \mathrm{kg}$ bw/day required to produce an effect. Nevertheless, 212 due to its very high exposure as a major constituent of alcoholic beverages, this situation is

213 completely reversed in terms of MOE, where now ethanol has the highest potency, as all other

214 substances occur at considerably lower concentrations in order to produce the same effect. The

215 observation that the MOE of ethanol is already in an effective dose range for the low risk

216 drinking guideline for females is absolutely in line with epidemiological observations. For breast

217 cancer, as an example, the largest pooled study on breast cancer shows significant effects for

218 lower than one drink daily. ${ }^{63}$

219 Interestingly, a similar comparative risk assessment that was recently conducted for tobacco

220 carcinogens $^{64}$ did not detect a single compound responsible for the carcinogenic effect as it was

221 in our case for ethanol in alcoholic beverages. In tobacco, acrolein, formaldehyde, and cadmium

222 all had MOEs down to below 10 and several other compounds had MOEs below $1000 .^{64}$

223 Our result for ethanol (MOE of 3.1 for one drink per day) is in excellent agreement with the 224 result from the Berkeley Carcinogenic Potency Database (CPDB) project, ${ }^{28}$ which reported a 225 MOE of 3 for moderate daily drinking (based on ethanol exposure of $326 \mathrm{mg} / \mathrm{kg} / \mathrm{day}$ ). It is of 226 note that the CPDB project uses different methodology to calculate MOE (based on adjusted $227 \mathrm{TD}_{50}$ values from older animal experiments ${ }^{65}$ and not $\mathrm{BMDL}_{10}$ from the most recent NTP study 228 as in our case ${ }^{21}$ ). As the results are almost the same, this independently validates our approach.

229 The CPDB project also reported data on NDMA in beer before 1979 (MOE of 1,000) and NDMA 230 in beer 1994-1995 (MOE of 50,000), which is also in agreement with our MOE results and the 
231 general observation that NDMA in beer is nowadays of negligible risk due to changes in 232 production technology. ${ }^{66}$

233 A limitation of our study is the fact that the MOE estimations for several of the other compounds 234 are not as robust as those for ethanol. For ethanol, not only the $\mathrm{BMDL}_{10}$ from animal experiments 235 is available but also human BMD modelling data for several endpoints including liver cirrhosis ${ }^{21}$ 236 as well as liver markers and blood pressure, ${ }^{67,68}$ all of which are in the same order of magnitude 237 confirming the validity and inter-species transferability of the animal data. As no BMDL for 238 cancer effect of ethanol was available in the literature, we used the animal BMDL for this study.

239 For several of the other compounds, no epidemiological data was available or it was inconclusive 240 (signified by classification into IARC groups $2 \mathrm{~A}$ and $2 \mathrm{~B}$ ). Two major problems of such 241 assessments remain: extrapolating between species as well as extrapolating from high-doses in 242 animals to low-doses in humans. ${ }^{69}$ Our approach would therefore rather overestimate the risks of 243 these agents compared to ethanol, for which these problems do not arise. A second limitation of 244 the study would also lead to overestimation of the risks of all compounds besides ethanol: the 245 limited database on occurrence data of these compounds in alcoholic beverages. For most of the 246 compounds large international surveys are missing, which would be necessary to provide more 247 robust exposure estimations. The exception of this is ethyl carbamate, for which large 248 international and EU-wide surveys have been conducted. ${ }^{9,10}$ Such data are especially lacking for 249 aflatoxins, cadmium, lead, and ochratoxin A. Several compounds also occur in only one category 250 of beverages (e.g., acrylamide and furan are only expected in beer, while 4-methylimidazole may 251 only occur in caramel-coloured products). In these cases, the absence of data can be explained by 252 the unlikelihood of occurrence, which explains that some groups of beverages were not studied at 253 all in the context of risk-oriented monitoring programs (see, e.g. Roth et al. ${ }^{70}$ ). We also assume 254 that there is a publication bias favouring positive results. ${ }^{71}$ From own experience in our research 
255 projects about unrecorded alcohol we know that it is much more problematic to publish survey

256 results indicating no public health relevance rather than alarmist reports of methanol deaths, for

257 example. From the typical lack of studies reporting absence of contamination in alcoholic

258 beverages, along with own experience as alcohol control authority (that routinely tests for

259 chemical contamination), we think that the occurrence data reported in table 2 are most likely

260 biased towards higher levels. This observation even strengthens our argumentation that ethanol is

261 the real risk factor in alcoholic beverages, as even with the available (most likely biased)

262 occurrence data, the MOEs of all other compounds are considerably higher than the MOE of 263 ethanol.

\section{Conclusion}

265 There are two main conclusions. First, the MOE approach is excellently suitable to provide 266 comparative risk assessments for lifestyle factors that are mixtures of several toxic compounds 267 such as alcoholic beverages. Second, ethanol was confirmed as by far the most important 268 carcinogen in alcoholic beverages. This confirms deductions by other approaches (such as genetic 269 epidemiology and mechanistic considerations, see introduction). This observation ultimately 270 leads to the question if mitigation measures for the other carcinogens (e.g. as currently conducted 271 for ethyl carbamate) are an adequate policy or if the money should not rather be spent on 272 reducing alcohol consumption per se, for which several cost-effective measures are already 273 available. ${ }^{72}$ The focus on alcohol policy would also not only reduce alcohol-related cancer but 274 alcohol-related harm in general. The German Federal Institute for Risk Assessment, for example, 275 holds the view in their assessment of acetaldehyde as contaminant of alcoholic beverages that 276 mitigation measures are not required in this case, as alcoholic beverages are health damaging 277 anyway. ${ }^{73}$ On the one hand, we agree of course with this statement as alcoholic beverages per se 
278 certainly pose inherent health risks. However, it also disregards the obligation of the regulating

279 agency to provide the safest possible environment. In modern societies we accept the fact that 280 citizens take risks, including risks, which are potentially lethal (e.g., by drinking alcohol or 281 exercising risky sports). However, within this risk taking the regulating agencies have to make 282 sure that the environment in which individual risk taking occurs is the safest possible (see 283 Refs. ${ }^{74,75}$ for further elaboration of these arguments). We would not argue to tolerate not closing a 284 ski slope with present danger of avalanche based on the reasoning that skiing is dangerous 285 anyway. In other words, reducing directly contained acetaldehyde in alcoholic beverages, which 286 is technically possible, ${ }^{35,76}$ should be targeted by regulating agencies, as it would reduce risk of 287 cancer independent of any individual risk decision. Our society cannot on the one hand tolerate 288 the use of alcoholic beverages and regulate them within food laws (as is the case in the European 289 Union) but then allow an exception regarding quality and safety. The individual drinker would 290 also most certainly select uncontaminated alcohol over contaminated alcohol.

291 In this context, it is noteworthy that for many of the mentioned contaminants, no maximum limits 292 are set by legislation that would allow adequate control and enforcement of quality standards. ${ }^{34}$

293 At least for one of the compounds, ethyl carbamate, mitigative risk management approaches are 294 ongoing but only on a "recommendation" basis. ${ }^{11}$ Inorganic compounds such as lead or arsenic 295 could be relevant for future research as was previously suggested in an analysis focused on 296 wine. ${ }^{77}$ However, the problem of lead is not restricted to alcoholic beverages, which contribute 297 only about $7 \%$ to the total lead exposure from foods and beverages. ${ }^{51}$ As the MOEs for total lead 298 exposure may reach down to $1,{ }^{51}$ risk management strategies outside of alcohol policy appear to 299 be necessary for this metal.

300 A final conclusion is the interesting observation that there is basically no substantial difference in 301 risk between unrecorded and recorded alcohol as it was sometimes differently purported by the 
302 alcohol industry. ${ }^{78}$ We also see no scientific basis for advertising claims that certain alcoholic

303 beverages are more or less carcinogenic than others (e.g. red wine less than spirits).

304

\section{Acknowledgements}

306 The authors thank Julie Grayson for English copy-editing of the manuscript. The research leading 307 to these results has been conducted in the context of establishing a methodology for comparative 308 risk assessment using the margin of exposure approach for the European Community's Seventh 309 Framework Programme under grant agreement $n^{\circ} 266813$ - Addiction and Lifestyles in 310 Contemporary Europe - Reframing Addictions Project (ALICE RAP). Participant organisations

311 in ALICE RAP can be seen at http://www.alicerap.eu/about-alice-rap/partners.html. Support to

312 CAMH for the salaries of scientists and infrastructure has been provided by the Ontario Ministry 313 of Health and Long Term Care. The contents of this paper are solely the responsibility of the 314 authors and do not necessarily represent the official views of the Ministry of Health and Long 315 Term Care or other funders. 


\section{References}

317 1. Lamy L. Étude de statistique clinique de 134 cas de cancer de l'œsophage et du cardia.

318 Arch Mal Appar Digest 1910;4:451-75.

2. IARC Working Group on the Evaluation of Carcinogenic Risks to Humans. Alcohol Drinking. IARC Monogr Eval Carcinog Risks Hum 1988;44:1-416.

3. IARC Working Group on the Evaluation of Carcinogenic Risks to Humans. Alcohol consumption and ethyl carbamate. IARC Monogr Eval Carcinog Risks Hum 2010;96:11428.

4. Secretan B, Straif K, Baan R, Grosse Y, El Ghissassi F, Bouvard V, Benbrahim-Tallaa L, Guha N, Freeman C, Galichet L, Cogliano V. A review of human carcinogens - Part E: tobacco, areca nut, alcohol, coal smoke, and salted fish. Lancet Oncol 2009;10:1033-4.

5. Baan R, Straif K, Grosse Y, Secretan B, El Ghissassi F, Bouvard V, Altieri A, Cogliano $\mathrm{V}$, WHO International Agency for Research on Cancer Monograph Working Group. Carcinogenicity of alcoholic beverages. Lancet Oncol 2007;8:292-3.

6. Beland FA, Benson RW, Mellick PW, Kovatch RM, Roberts DW, Fang JL, Doerge DR. Effect of ethanol on the tumorigenicity of urethane (ethyl carbamate) in B6C3F1 mice. Food Chem Toxicol 2005;43:1-19.

7. Soffritti M, Belpoggi F, Cevolani D, Guarino M, Padovani M, Maltoni C. Results of longterm experimental studies on the carcinogenicity of methyl alcohol and ethyl alcohol in rats. Ann N Y Acad Sci 2002;982:46-69.

8. Johnson \& Johnson. Listerine - FAQs for Professionals. URL:http://www.listerine.com.sg/faqs-for-professionals.html. Accessed: 2011-10-18. (Archived by WebCite® at http://www.webcitation.org/62Wfznhct): Johnson \& Johnson Pte. Ltd., 2011.

9. EFSA. Ethyl carbamate and hydrocyanic acid in food and beverages. EFSA J 2007;551:144.

10. Vavasour E, Renwick AG, Engeli B, Barlow S, Castle L, DiNovi M, Slob W, Schlatter J, Bolger M. Ethyl carbamate. WHO Food Additives Series 55. Safety evaluation of certain contaminants in food. Prepared by the sixty-fourth meeting of the Joint FAO/WHO Expert Committee on Food Additives (JECFA). Geneva, Switzerland: WHO and FAO, 2006:205316.

11. European Commission. Commission Recommendation of 2 March 2010 on the prevention and reduction of ethyl carbamate contamination in stone fruit spirits and stone fruit marc spirits and on the monitoring of ethyl carbamate levels in these beverages. Off $J$ Europ Union 2010;L52:53-7. 
351

352

353

354

355

356

357

358

359

360

361

362

363

364

365

366

367

368

369

370

371

372

373

374

375

376

377

378

379

380

381

382

383

384

385

386
12. Spiegelhalder B, Eisenbrand G, Preussmann R. Contamination of beer with trace quantities of $N$-nitrosodimethylamine. Food Cosmet Toxicol 1979;17:29-31.

13. Rehm J, Kanteres F, Lachenmeier DW. Unrecorded consumption, quality of alcohol and health consequences. Drug Alcohol Rev 2010;29:426-36.

14. Lachenmeier DW, Leitz J, Schoeberl K, Kuballa T, Straub I, Rehm J. Quality of illegally and informally produced alcohol in Europe: Results from the AMPHORA project. Adicciones 2011;23:133-40.

15. Barlow S, Renwick AG, Kleiner J, Bridges JW, Busk L, Dybing E, Edler L, Eisenbrand G, Fink-Gremmels J, Knaap A, Kroes R, Liem D, et al. Risk assessment of substances that are both genotoxic and carcinogenic. Report of an International Conference organized by EFSA and WHO with support of ILSI Europe. Food Chem Toxicol 2006;44:1636-50.

16. IPCS. Environmental Health Criteria 240: Principles and Methods for the Risk Assessment of Chemicals in Food. Geneva: World Health Organization, 2009.

17. EFSA. Opinion of the Scientific Committee on a request from EFSA related to a harmonised approach for risk assessment of substances which are both genotoxic and carcinogenic. EFSA J 2005;282:1-31.

18. Benford D, Bolger PM, Carthew P, Coulet M, DiNovi M, Leblanc JC, Renwick AG, Setzer W, Schlatter J, Smith B, Slob W, Williams G, et al. Application of the Margin of Exposure (MOE) approach to substances in food that are genotoxic and carcinogenic. Food Chem Toxicol 2010;48:S2-S24.

19. Crump KS. A new method for determining allowable daily intakes. Fundam Appl Toxicol 1984;4:854-71.

20. U.S.EPA. The use of the benchmark dose approach in health risk assessment. EPA/630/R94/007. Washington, DC.: Office of Research and Development. US Environmental Protection Agency, 1995.

21. Lachenmeier DW, Kanteres F, Rehm J. Epidemiology-based risk assessment using the benchmark dose/margin of exposure approach: the example of ethanol and liver cirrhosis. Int J Epidemiol 2011;40:210-8.

22. CAMH. Low-risk drinking guidelines [pamphlet]. Toronto, Canada: Centre for Addiction and Mental Health, 2005.

23. Jendral JA, Monakhova YB, Lachenmeier DW. Formaldehyde in alcoholic beverages: large chemical survey using purpald screening followed by chromotropic acid spectrophotometry with multivariate curve resolution. Int J Anal Chem 2011;2011:Article ID 797604.

24. Klejdus B, Moravcová J, Lojková L, Vacek J, Kubán V. Solid phase extraction of 4(5)methylimidazole (4MeI) and 2-acetyl-4(5)-(1,2,3,4-tetrahydroxybutyl)-imidazole (THI)

John Wiley \& Sons, Inc. 
Comparative risk assessment of carcinogens in alcoholic beverages

from foods and beverages with subsequent liquid chromatographic electrospray mass spectrometric quantification. J Sep Sci 2006;29:378-84.

25. Yoshikawa S, Fujiwara M. Determination of 4(5)-methylimidazole in food by thin layer chromatography. J Food Hyg Soc Jap 1981;22:189-96.

26. Grosse Y, Baan R, Secretan-Lauby B, El Ghissassi F, Bouvard V, Benbrahim-Tallaa L, Guha N, Islami F, Galichet L, Straif K. Carcinogenicity of chemicals in industrial and consumer products, food contaminants and flavourings, and water chlorination byproducts. Lancet Oncol 2011;12:328-9.

27. Curro P, Micali G, Lanuzza F. Determination of beta-asarone, safrole, isosafrole and anethole in alcoholic drinks by high-performance liquid chromatography. J Chromatogr 1987;404:273-8.

28. Gold LS, Ames BN, Slone TH. How Many Fold Lower Is Human Exposure Than the Dose That Gave Rodents Cancer: Margin of Exposure, MOE (Rodent Cancer Dose/Human Exposure). Berkeley, CA. URL:http://potency.berkeley.edu/MOEtable.html. Accessed: 2009-08-11. (Archived by WebCite® at http://www.webcitation.org/5ix20tFMx): Carcinogenic Potency Project, University of California, Berkeley, 2008.

29. Mably M, Mankotia M, Cavlovic P, Tam J, Wong L, Pantazopoulos P, Calway P, Scott PM. Survey of aflatoxins in beer sold in Canada. Food Addit Contam 2005;22:1252-7.

30. EFSA. Update on furan levels in food from monitoring years 2004-2010 and exposure assessment. EFSA J 2011;9:2347.

31. Donhauser S, Wagner D, Jacob F. Critical Trace-Elements in Brewing Technology. 2. Occurrence of Arsenic, Lead, Cadmium, Chromium, Mercury and Selenium in Beer. Monatsschr Brauwissensch 1987;40:328-33.

32. Andrey D, Beuggert H, Ceschi M, Corvi C, de Rossa M, Herrmann A, Klein B, ProbstHensch N. Monitoring-Programm 'Schwermetalle in Lebensmitteln'. IV. Blei, Cadmium, Kupfer und Zink in Weinen auf dem Schweizer Markt. Teil B: Vorgehen, Resultate und Diskussion. [Monitoring programme for heavy metals in food. IV. Lead, cadmium, copper and zinc in wine on the Swiss market. Part B: methods, results and discussion.]. Mitt Geb Lebensm Hyg 1992;83:711-36.

33. Gutsche B, Weisshaar R, Buhlert J. Acrylamide in food - screening results from food control in Baden-Württemberg. Deut Lebensm Rundsch 2002;98:437-43.

34. Lachenmeier DW, Schoeberl K, Kanteres F, Kuballa T, Sohnius E-M, Rehm J. Is contaminated alcohol a health problem in the European Union? A review of existing and methodological outline for future studies. Addiction 2011;106 (Suppl.1):20-30.

35. Lachenmeier DW, Kanteres F, Rehm J. Carcinogenicity of acetaldehyde in alcoholic beverages: Risk assessment outside ethanol metabolism. Addiction 2009;104:533-50. 
424

425

426

427

428

429

430

431

432

433

434

435

436

437

438

439

440

441

442

443

444

445

446

447

448

449

450

451

452

453

454

455

456

457

458

459

460
36. Soffritti M, Belpoggi F, Lambertin L, Lauriola M, Padovani M, Maltoni C. Results of long-term experimental studies on the carcinogenicity of formaldehyde and acetaldehyde in rats. Ann N Y Acad Sci 2002;982:87-105.

37. Mueller U, Agudo A, Carrington C, Doerge D, Hellenäs KE, Leblanc JC, Rao M, Renwick A, Slob W, Wu Y. Acrylamide (Addendum). WHO Food Additives Series 63. Safety evaluation of certain contaminants in food. Prepared by the seventy-second meeting of the Joint FAO/WHO Expert Committee on Food Additives (JECFA). Geneva, Switzerland: WHO and FAO, 2011:1-151.

38. NTP. NTP technical report on the toxicology and carcinogensis. Studies of acrylamide (CAS No. 79-06-1) in F344/N rats and B6C3F1 mice (drinking water study). Natl Toxicol Program Tech Rep Ser 2011;in press.

39. EFSA. Opinion of the scientific panel on contaminants in the food chain on a request from the commission related to the potential increase of consumer health risk by a possible increase of the existing maximum levels for aflatoxins in almonds, hazelnuts and pistachios and derived products. EFSA J 2007;446:1-127.

40. Yeh FS, Yu MC, Mo CC, Luo S, Tong MJ, Henderson BE. Hepatitis B virus, aflatoxins, and hepatocellular carcinoma in southern Guangxi, China. Cancer Res 1989;49:2506-9.

41. Benford DJ, Alexander J, Baines J, Bellinger DC, Carrington C, Devesa i Peréz VA, uxbury J, Fawell J, Hailemariam K, Montoro R, Ng J, Slob W, et al. Arsenic (Addendum). WHO Food Additives Series 63. Safety evaluation of certain contaminants in food. Prepared by the seventy-second meeting of the Joint FAO/WHO Expert Committee on Food Additives (JECFA). Geneva, Switzerland: WHO and FAO, 2011:153316.

42. Chen CL, Chiou HY, Hsu LI, Hsueh YM, Wu MM, Chen CJ. Ingested arsenic, characteristics of well water consumption and risk of different histological types of lung cancer in northeastern Taiwan. Environ Res 2010;110:455-62.

43. U.S.EPA. Benzene (CASRN 71-43-2). Integrated Risk Information System. Document 0276. Washington, DC: U.S. Environmental Protection Ageny, 2003.

44. Rothman N, Li GL, Dosemeci M, Bechtold WE, Marti GE, Wang YZ, Linet M, Xi LQ, Lu W, Smith MT, Titenko-Holland N, Zhang LP, et al. Hematotoxicity among Chinese workers heavily exposed to benzene. Am J Ind Med 1996;29:236-46.

45. U.S.EPA. Cadmium (CASRN 7440-43-9). Integrated Risk Information System. Document 0141. Washington, DC: U.S. Environmental Protection Ageny, 1998.

46. NTP. NTP technical report on the toxicology and carcinogensis. Studies of urethane, ethanol, and urethane/ethanol (urethane, CAS No. 51-79-6; ethanol, CAS No. 64-17-5) in B6C3F1 mice (drinking water studies). Natl Toxicol Program Tech Rep Ser 2004;510:1346. 
Comparative risk assessment of carcinogens in alcoholic beverages

461

462

463

464

465

466

467

468

469

470

471

472

473

474

475

476

477

478

479

480

481

482

483

484

485

486

487

488

489

490

491

492

493

494

495

496

47. IPCS. Formaldehyde. Concise international chemical assessment document 40. Geneva: World Health Organization, 2002.

48. Til HP, Woutersen RA, Feron VJ, Hollanders VH, Falke HE, Clary JJ. Two-year drinking-water study of formaldehyde in rats. Food Chem Toxicol 1989;27:77-87.

49. Williams GM, Arisseto AP, Baines J, DiNovi M, Feeley M, Schlatter J, Slob W, Toledo MCF, Vavasour E. Furan. WHO Food Additives Series 63. Safety evaluation of certain contaminants in food. Prepared by the seventy-second meeting of the Joint FAO/WHO Expert Committee on Food Additives (JECFA). Geneva, Switzerland: WHO and FAO, 2011:487-603.

50. Moser GJ, Foley J, Burnett M, Goldsworthy TL, Maronpot R. Furan-induced doseresponse relationships for liver cytotoxicity, cell proliferation, and tumorigenicity (furaninduced liver tumorigenicity). Exp Toxicol Pathol 2009;61:101-11.

51. EFSA. Scientific opinion on lead in food. EFSA J 2010;8:1570.

52. Navas-Acien A, Tellez-Plaza M, Guallar E, Muntner P, Silbergeld E, Jaar B, Weaver V. Blood cadmium and lead and chronic kidney disease in US adults: a joint analysis. Am J Epidemiol 2009;170:1156-64.

53. EFSA. Scientific opinion on the re-evaluation of caramel colours (E $150 \mathrm{a}, \mathrm{b}, \mathrm{c}, \mathrm{d})$ as food additives. EFSA J 2011;9:2004.

54. NTP. Toxicology and carcinogenesis studies of 4-methylimidazole (Cas No. 822-36-6) in F344/N rats and B6C3F1 mice (feed studies). Natl Toxicol Program Tech Rep Ser 2007;535:1-274.

55. Zeilmaker MJ, Bakker MI, Schothorst R, Slob W. Risk assessment of Nnitrosodimethylamine formed endogenously after fish-with-vegetable meals. Toxicol Sci 2010;116:323-35.

56. Peto R, Gray R, Brantom P, Grasso P. Dose and time relationships for tumor induction in the liver and esophagus of 4080 inbred rats by chronic ingestion of $\mathrm{N}$-nitrosodiethylamine or N-nitrosodimethylamine. Cancer Res 1991;51:6452-69.

57. Peto R, Gray R, Brantom P, Grasso P. Effects on 4080 rats of chronic ingestion of Nnitrosodiethylamine or N-nitrosodimethylamine: a detailed dose-response study. Cancer Res 1991;51:6415-51.

58. Barlow S, Bolger M, Pitt JI, Verger P. Ochratoxin A (addendum). WHO Food Additives Series 59. Safety evaluation of certain contaminants in food. Prepared by the sixty-eighth meeting of the Joint FAO/WHO Expert Committee on Food Additives (JECFA). Geneva, Switzerland: WHO and FAO, 2008:357-429.

59. NTP. Toxicology and carcinogenesis studies of ochratoxin A (CAS No. 303-47-9) in F344/N rats (gavage studies). Natl Toxicol Program Tech Rep Ser 1989;358:1-142. 
497

498

499

500

501

502

503

504

505

506

507

508

509

510

511

512

513

514

515

516

517

518

519

520

521

522

523

524

525

526

527

528

529

530

531

532
60. Martati E, Boersma MG, Spenkelink A, Khadka DB, Punt A, Vervoort J, van Bladeren PJ, Rietjens IM. Physiologically based biokinetic (PBBK) model for safrole bioactivation and detoxification in rats. Chem Res Toxicol 2011;24:818-34.

61. Boberg EW, Miller EC, Miller JA, Poland A, Liem A. Strong evidence from studies with brachymorphic mice and pentachlorophenol that 1'-sulfooxysafrole is the major ultimate electrophilic and carcinogenic metabolite of 1'-hydroxysafrole in mouse liver. Cancer Res 1983;43:5163-73.

62. Miller EC, Swanson AB, Phillips DH, Fletcher TL, Liem A, Miller JA. Structure-activity studies of the carcinogenicities in the mouse and rat of some naturally occurring and synthetic alkenylbenzene derivatives related to safrole and estragole. Cancer Res 1983;43:1124-34.

63. Hamajima N, Hirose K, Tajima K, Rohan T, Calle EE, Heath CW, Jr., Coates RJ, Liff JM, Talamini R, Chantarakul N, Koetsawang S, Rachawat D, et al. Alcohol, tobacco and breast cancer--collaborative reanalysis of individual data from 53 epidemiological studies, including 58,515 women with breast cancer and 95,067 women without the disease. $\mathrm{Br} \mathrm{J}$ Cancer 2002;87:1234-45.

64. Cunningham FH, Fiebelkorn S, Johnson M, Meredith C. A novel application of the Margin of Exposure approach: Segregation of tobacco smoke toxicants. Food Chem Toxicol 2011;49:2921-33.

65. Gold LS, Slone TH, Bernstein L. Summary of carcinogenic potency and positivity for 492 rodent carcinogens in the carcinogenic potency database. Environ Health Perspect 1989;79:259-72.

66. Lachenmeier DW, Fügel D. Reduction of Nitrosamines in Beer - Review of a Success Story. Brewing Science 2007;60:84-9.

67. Dakeishi M, Iwata T, Ishii N, Murata K. Effects of alcohol consumption on hepatocellular injury in Japanese men. Tohoku J Exp Med 2004;202:31-9.

68. Dakeishi M, Murata K, Tamura A, Iwata T. Relation between benchmark dose and noobserved-adverse-effect level in clinical research: effects of daily alcohol intake on blood pressure in Japanese salesmen. Risk Anal 2006;26:115-23.

69. Gold LS, Slone TH, Manley NB, Ames BN. Misconceptions about the causes of cancer. Vancouver, British Columbia, Canada: The Fraser Institute, 2002.

70. Roth M, Hartmann S, Renner R, Hörtig W. Sampling on a risk basis in the context of official control in the German federal state Baden-Württemberg. Deut Lebensm Rundsch 2007; 103:45-52.

71. Dwan K, Altman DG, Arnaiz JA, Bloom J, Chan AW, Cronin E, Decullier E, Easterbrook PJ, Von Elm E, Gamble C, Ghersi D, Ioannidis JP, et al. Systematic review of the 
empirical evidence of study publication bias and outcome reporting bias. PLoS One 2008;3:e3081.

72. Babor T, Caetano R, Casswell S, Edwards G, Giesbrecht N, Graham K, Grube J, Hill L, Holder H, Homel R, Livingstone M, Österberg E, et al. Alcohol: No ordinary commodity. Research and public policy. 2nd edition. Oxford, UK: Oxford University Press, 2010.

73. BfR. Gesundheitliche Bewertung von Acetaldehyd in alkoholischen Getränken. Aktualisierte Stellungnahme Nr. 022/2010 des BfR vom 04. Mai 2010. Berlin:

Bundesinstitut für Risikobewertung, 2010.

74. Rehm J, Patra J. Different guidelines for different countries? On the scientific basis of low-risk drinking guidelines and their implications. Drug Alcohol Rev 2011; in press, DOI: 10.1111/j.1465-3362.2011.00395.x.

75. Room R, Rehm J. Clear criteria based on absolute risk: Reforming the basis of guidelines on low-risk drinking. Drug Alcohol Rev 2011;in press, DOI: 10.1111/j.14653362.2011.00398.x.

76. Lachenmeier DW, Sohnius E-M. The role of acetaldehyde outside ethanol metabolism in the carcinogenicity of alcoholic beverages: Evidence from a large chemical survey. Food Chem Toxicol 2008;46:2903-11.

77. Naughton DP, Petróczi A. Heavy metal ions in wines: meta-analysis of target hazard quotients reveal health risks. Chem Cent J 2008;2:22.

78. Lachenmeier DW, Rehm J. Unrecorded alcohol: A threat to public health? Addiction 2009;104:875-7. 
556 557 558

Table 1. Summary of WHO International Agency for Research on Cancer (IARC) evaluation of carcinogenicity of substances that may be present in alcoholic beverages (updated from $\mathrm{IARC}^{3}$ )

\begin{tabular}{|c|c|c|c|c|}
\hline \multirow{2}{*}{ Agent } & \multicolumn{3}{|c|}{$\begin{array}{l}\text { IARC Monographs evaluation of } \\
\text { Carcinogenicity }\end{array}$} & \multirow{2}{*}{$\begin{array}{l}\text { IARC Monographs (Volume } \\
\text { Number) }\end{array}$} \\
\hline & In animals & In humans & $\begin{array}{l}\text { IARC } \\
\text { group }\end{array}$ & \\
\hline $\begin{array}{l}\text { Acetaldehyde associated with } \\
\text { consumption of alcoholic } \\
\text { beverages }\end{array}$ & Sufficient & Sufficient & 1 & $36, \operatorname{Sup} 7,71,100 E$ \\
\hline Acrylamide & Sufficient & Inadequate & $2 \mathrm{~A}$ & 60 \\
\hline Aflatoxins & Sufficient & Sufficient & 1 & $56,82,100 \mathrm{~F}$ \\
\hline Arsenic & Sufficient & Sufficient & 1 & 23, Sup 7, 100C \\
\hline Benzene & Sufficient & Sufficient & 1 & 29, Sup 7, 100F \\
\hline Cadmium & Sufficient & Sufficient & 1 & $58,100 \mathrm{C}$ \\
\hline $\begin{array}{l}\text { Ethanol in alcoholic } \\
\text { beverages }\end{array}$ & Sufficient & Sufficient & 1 & $44,96,100 \mathrm{E}$ \\
\hline Ethyl carbamate (urethane) & Sufficient & Inadequate & $2 \mathrm{~A}$ & 7, Sup 7, 96 \\
\hline Formaldehyde & Sufficient & Sufficient & 1 & $88,100 F$ \\
\hline Furan & Sufficient & Inadequate & $2 \mathrm{~B}$ & 63 \\
\hline Lead compounds, inorganic & Sufficient & Limited & $2 \mathrm{~A}$ & 87 \\
\hline 4-Methylimidazole & Sufficient & Inadequate & 2B & 101 \\
\hline$N$-Nitrosodimethylamine & Sufficient & Inadequate & $2 \mathrm{~A}$ & 17, Sup 7 \\
\hline Ochratoxin A & Sufficient & Inadequate & $2 \mathrm{~B}$ & 56 \\
\hline Safrole & Sufficient & Inadequate & $2 \mathrm{~B}$ & 10, Sup 7 \\
\hline
\end{tabular}

559 a Group 1: Carcinogenic to humans; Group 2A: Probably carcinogenic to humans; Group 2B: 560 Possibly carcinogenic to humans (for definitions of groups, see monographs.iarc.fr). 
Comparative risk assessment of carcinogens in alcoholic beverages

561 Table 2. Occurrence of WHO International Agency for Research on Cancer (IARC) carcinogens 562 in alcoholic beverages

\begin{tabular}{|c|c|c|}
\hline Agent & Amount in alcoholic beverages (Average/Maximum) ${ }^{\mathbf{a}}$ & $\begin{array}{l}\text { Amount in unrecorded alcohol } \\
\text { (Average/Maximum) }\end{array}$ \\
\hline $\begin{array}{l}\text { Acetaldehyde associated with } \\
\text { consumption of alcoholic } \\
\text { beverages }\end{array}$ & $9 / 63 \mathrm{mg} / \mathrm{l}$ (beer); 34/211 mg/l (wine); 66/1159 mg/l (spirits) ${ }^{76}$ & $90 / 822 \mathrm{mg} / \mathrm{l}$ \\
\hline Acrylamide & $0-72 \mu \mathrm{g} / \mathrm{kg}$ (beer) ${ }^{\mathrm{c}}$ & (no data) \\
\hline Aflatoxins & $0.002 / 0.230 \mu \mathrm{g} / \mathrm{L}$ (beer) ${ }^{29}$ & (not detectable in all samples) \\
\hline Arsenic & 0/102.4 $\mu \mathrm{g} / \mathrm{L}$ (beer); 4/14.6 $\mu \mathrm{g} / \mathrm{L}$ (wine); 13/27 $\mu \mathrm{g} / \mathrm{L}$ (spirits) & (not detectable in all samples) \\
\hline Benzene & $10 / 20 \mu \mathrm{g} / \mathrm{L}$ in beer produced with contaminated $\mathrm{CO}_{2}$ & (no data) \\
\hline Cadmium & $0.9 / 14.3 \mu \mathrm{g} / \mathrm{L}$ (beer); $1.0 / 30 \mu \mathrm{g} / \mathrm{L}$ (wine) $6 / 40 \mu \mathrm{g} / \mathrm{L}$ (spirits) & $0 / 0.04 \mathrm{mg} / \mathrm{L}$ \\
\hline $\begin{array}{l}\text { Ethanol in alcoholic } \\
\text { beverages }\end{array}$ & $(2-80 \%$ vol $)$ & $(10-89 \%$ vol $)$ \\
\hline Ethyl carbamate (urethane) & $\begin{array}{l}0 / 33 \mu \mathrm{g} / \mathrm{kg} \text { (beer); } 5 / 180 \mu \mathrm{g} / \mathrm{kg} \text { (wine); } 93 / 6730 \mu \mathrm{g} / \mathrm{kg} \text { (spirits) } \\
744 / 22000 \mu \mathrm{g} / \mathrm{kg} \text { (fruit spirits) }{ }_{9} \text { ) }\end{array}$ & $0.5 / 5.4 \mathrm{mg} / \mathrm{L}$ \\
\hline Formaldehyde & $0 \mathrm{mg} / \mathrm{L}$ (beer); 0.13/1.15 mg/L (wine); 0.50/14.37 mg/L (spirits) ${ }^{23}$ & $0.22 / 6.71 \mathrm{mg} / \mathrm{L}^{23}$ \\
\hline Furan & $3.3 / 28 \mu \mathrm{g} / \mathrm{kg}(\text { beer })^{30}$ & (no data) \\
\hline Lead compounds, inorganic & $2 / 15 \mu \mathrm{g} / \mathrm{L}$ (beer) ${ }^{31} ; 57 / 326 \mu \mathrm{g} / \mathrm{L}$ (wine) ${ }^{32} ; 31 / 600 \mu \mathrm{g} / \mathrm{L}$ (spirits) & $0.03 / 1.4 \mathrm{mg} / \mathrm{L}$ \\
\hline 4-Methylimidazole & $\begin{array}{l}\text { Caramel colored products: } 9 / 28 \mu \mathrm{g} / \mathrm{L} \text { in dark beer }{ }^{24} ; 0 / 0.14 \mathrm{mg} / \mathrm{L} \text { in } \\
\text { whisky }\end{array}$ & (no data) \\
\hline$N$-Nitrosodimethylamine & $0.1 / 1.3 \mu \mathrm{g} / \mathrm{kg}$ (beer) & (no data) \\
\hline Ochratoxin A & $0.05 / 1.5 \mu \mathrm{g} / \mathrm{L}$ (beer); 0.23/7.0 $\mu \mathrm{g} / \mathrm{L}$ (wine) & (no data) \\
\hline Safrole & $0 / 6.6 \mathrm{mg} / \mathrm{l}$ (bitters/liqueurs/aperitifs) ${ }^{27}$ & (no data) \\
\hline
\end{tabular}

$563{ }^{a}$ If no other source is stated, the data are taken from the IARC literature review ${ }^{3}$ by calculating 564 the average over all studies. Historical data (i.e. prior to implementation of mitigation 565 measures) was not included.

${ }^{b}$ If no other source is stated, the data are taken from an European sample of unrecorded alcohol ${ }^{14}$

${ }^{c}$ Few surveys on acrylamide in alcoholic beverages are available. The majority of analyzed samples contained levels below the detection limit. The level of $72 \mu \mathrm{g} / \mathrm{kg}$ was reported in a single sample of wheat beer. ${ }^{33}$ 
Table 3. Dose response modelling results of WHO International Agency for Research on Cancer (IARC) carcinogens occurring in alcoholic beverages

\begin{tabular}{|c|c|c|c|c|}
\hline Agent & $\begin{array}{l}\text { Toxicological Endpoint for } \\
\text { Modelling a }\end{array}$ & \begin{tabular}{|l|} 
Reference for \\
Dose-Response \\
Modelling Study
\end{tabular} & $\begin{array}{l}\text { Reference for } \\
\text { Original Data used } \\
\text { for Modelling }\end{array}$ & $\begin{array}{l}\mathrm{BMDL}_{10}{ }^{\mathrm{b}} \\
{[\mathrm{mg} / \mathrm{kg} \text { bw/day }]}\end{array}$ \\
\hline Acetaldehyde & $\begin{array}{l}\text { Tumour-bearing animals in } \\
\text { male rats }\end{array}$ & & & 56 \\
\hline Acrylamide & $\begin{array}{l}\text { Harderian gland tumours in } \\
\text { mice }\end{array}$ & & 38 & 0.18 \\
\hline Aflatoxin $B_{1}$ & Liver cancer in humans & 39 & 40 & 0.00087 \\
\hline Arsenic & Lung cancer in humans & FT & +2 & BMDL $0.5: 0.003$ \\
\hline Benzene & Lymphocyte count in humans & 43 & $4+4$ & 1.2 \\
\hline Cadmium & $\begin{array}{l}\text { Human studies involving } \\
\text { chronic exposures }\end{array}$ & & 45 & NOAEL: $0.01^{\mathrm{c}}$ \\
\hline Ethanol & $\begin{array}{l}\text { Hepatocellular adenoma or } \\
\text { carcinoma in rats }\end{array}$ & ${ }^{21}$ & 6,46 & 700 \\
\hline Ethyl carbamate (urethane) & $\begin{array}{l}\text { Alveolar and bronchiolar } \\
\text { neoplasms in mice }\end{array}$ & & 46 & 0.3 \\
\hline Formaldehyde & $\begin{array}{l}\text { Histological changes in the } \\
\text { aerodigestive tract, including } \\
\text { oral and gastrointestinal } \\
\text { mucosa of rats }\end{array}$ & & 48 & NOEL: $15^{\mathrm{c}}$ \\
\hline Furan & $\begin{array}{l}\text { Hepatocellular adenomas and } \\
\text { carcinomas in female mice }\end{array}$ & & 50 & 0.96 \\
\hline Lead & $\begin{array}{l}\text { Cardiovascular effects in } \\
\text { humans }\end{array}$ & & $p^{2}$ & BMDL $_{01}: 0.0015$ \\
\hline 4-Methylimidazole & Cancer of the lung in mice & $\mathrm{p}^{3}$ & 54 & NOAEL: $80^{\circ}$ \\
\hline $\mathrm{N}$-Nitrosodimethylamine & Total liver tumors & & 86,57 & 0.029 \\
\hline Ochratoxin A & $\begin{array}{l}\text { Kidney adenoma and } \\
\text { carcinoma in male rats }\end{array}$ & & & 0.025 \\
\hline Safrole & Hepatic tumors in mice & 60 & 61,62 & $3^{\mathrm{d}}$ \\
\hline
\end{tabular}

${ }^{\mathrm{a}}$ Human data was preferred over animal data, if available. Non-cancer endpoints were chosen if dose-response modelling for cancer effects was unavailable (such as in the case of lead). The most sensitive endpoint was chosen if dose-response data for several organ sites were available.

${ }^{\mathrm{b}} \mathrm{BMDL}_{\mathrm{x}}$ : lower one-sided confidence limit of the benchmark dose (BMD) for a $\mathrm{x} \%$ incidence of health effect.

${ }^{c}$ No usable BMD-modelling for oral exposure was identified in the literature. The No Effect Level (NOEL) or No Observed Adverse Effect Level (NOAEL) are used in these cases instead.

${ }^{\mathrm{d}}$ A range of "approximately 3-29 mg/kg bw/day" was provided as BMDL 10 for safrole ${ }^{60}$. As no further rationale was provided in the study, we chose the minimum of this range to provide a conservative assessment. 
Comparative risk assessment of carcinogens in alcoholic beverages

585

Table 4. Margin of Exposure (MOE) of WHO International Agency for Research on Cancer contamination scenarios $(\mathrm{MOE}=\mathrm{BMDL}$ or $\mathrm{NO}(\mathrm{A}) \mathrm{EL} /$ Exposure $)$

\begin{tabular}{|c|c|c|c|c|c|}
\hline \multirow[b]{2}{*}{ Agent } & \multirow[b]{2}{*}{ Type of alcohol } & \multicolumn{4}{|c|}{$\begin{array}{l}\begin{array}{l}\text { Scenario 1: One standard drink Scenario 2: Heavy drinker (4 standard } \\
\text { per day (low risk drinking } \\
\begin{array}{l}\text { guideline for females) } \\
\text { a }\end{array}\end{array} \quad \text { drinks per day, own categorization) } \\
\end{array}$} \\
\hline & & $\begin{array}{l}\text { MOE for average } \\
\text { contamination }\end{array}$ & $\begin{array}{l}\text { MOE for } \\
\text { maximum } \\
\text { contamination } \\
\text { (Worst case) }\end{array}$ & $\begin{array}{l}\text { MOE for average } \\
\text { contamination }\end{array}$ & $\begin{array}{l}\text { MOE for maximum } \\
\text { contamination (Worst } \\
\text { case) }\end{array}$ \\
\hline \multirow[t]{4}{*}{ Acetaldehyde ${ }^{b}$} & Beer & 1095 & 156 & 274 & 39 \\
\hline & Wine & 696 & 112 & 174 & 28 \\
\hline & Spirits & 1184 & 67 & 296 & 17 \\
\hline & Unrecorded & 868 & 95 & 217 & 24 \\
\hline Acrylamide & Beer & $\infty^{c}$ & 440 & $\infty$ & 110 \\
\hline Aflatoxin $\mathrm{B}_{1}$ & Beer & 76540 & 666 & 19135 & 166 \\
\hline \multirow[t]{3}{*}{ Arsenic } & Beer & $\infty$ & 5 & $\infty$ & 1 \\
\hline & Wine & 317 & 87 & 79 & 22 \\
\hline & Spirits & 322 & 155 & 81 & 39 \\
\hline Benzene & Beer & 21114 & 10557 & 5279 & 2639 \\
\hline \multirow[t]{4}{*}{ Cadmium } & Beer & 1955 & 123 & 489 & 31 \\
\hline & Wine & 4225 & 141 & 1056 & 35 \\
\hline & Spirits & 2326 & 349 & 581 & 87 \\
\hline & Unrecorded & $\infty$ & 349 & $\infty$ & 87 \\
\hline Ethanol & All & 3.1 & - & 0.8 & - \\
\hline \multirow{5}{*}{$\begin{array}{l}\text { Ethyl carbamate } \\
\text { (urethane) }\end{array}$} & Beer & $\infty$ & 1600 & $\infty$ & 400 \\
\hline & Wine & 25352 & 704 & 6338 & 176 \\
\hline & Spirits & 4501 & 62 & 1125 & 16 \\
\hline & Fruit spirits & 563 & 19 & 141 & 5 \\
\hline & Unrecorded & 837 & 78 & 209 & 19 \\
\hline \multirow[t]{4}{*}{ Formaldehyde } & Beer & $\infty$ & $\infty$ & $\infty$ & $\infty$ \\
\hline & Wine & 48754 & 5511 & 12189 & 1378 \\
\hline & Spirits & 41860 & 1457 & 10465 & 364 \\
\hline & Unrecorded & 95137 & 3119 & 23784 & 780 \\
\hline Furan & Beer & 51186 & 6033 & 12797 & 1508 \\
\hline \multirow[t]{4}{*}{ Lead } & Beer & 132 & 17.6 & 33 & 4.4 \\
\hline & Wine & 11 & 1.9 & 2.8 & 0.5 \\
\hline & Spirits & 68 & 3.5 & 17 & 0.9 \\
\hline & Unrecorded & 70 & 1.5 & 17 & 0.4 \\
\hline \multirow[t]{2}{*}{ 4-Methylimidazole } & Caramel-coloured Beer & 1564027 & 502723 & 391007 & 125681 \\
\hline & $\begin{array}{l}\text { Caramel-coloured } \\
\text { Whisky }\end{array}$ & $\infty$ & 797342 & $\infty$ & 199336 \\
\hline $\begin{array}{l}N- \\
\text { Nitrosodimethylamine } \\
\end{array}$ & Beer & 51026 & 3925 & 12757 & 981 \\
\hline \multirow[t]{2}{*}{ Ochratoxin A } & Beer & 87977 & 2933 & 21994 & 733 \\
\hline & Wine & 45928 & 1509 & 11482 & 377 \\
\hline Safrole & $\begin{array}{l}\text { Bitters/Liqueurs/Aperitif } \\
\mathrm{s}\end{array}$ & $\infty$ & 634 & $\infty$ & 159 \\
\hline
\end{tabular}

${ }^{\mathrm{b}}$ A standard drink in Canada is considered to have a total of 13.6 grams of alcohol ${ }^{22}$. To recalculate the amount of contaminants per $\mathrm{L}$ or per $\mathrm{kg}$ to standard drink, portions of 341 $\mathrm{ml}$ (beer), $142 \mathrm{ml}$ (wine), $43 \mathrm{ml}$ (spirits and unrecorded) were chosen ${ }^{22}$. As no density was given in any of the contamination studies, $1 \mathrm{~kg}$ was set to equal $1 \mathrm{~L}$ for recalculation to volume if necessary. The exposure was estimated for the different drinking scenarios based on the occurrence data in Table 2 and a body weight of $60 \mathrm{~kg}$. 
$594{ }^{\mathrm{b}}$ Acetaldehyde directly contained in the beverages excluding metabolically formed acetaldehyde. $595{ }^{c}$ The lemniscate symbol indicates that the MOE was not calculable as the exposure was zero (i.e. 596 below the detection limit of the applied analytical methodology) 
2

3

4

5

6

10
597

598

599 600

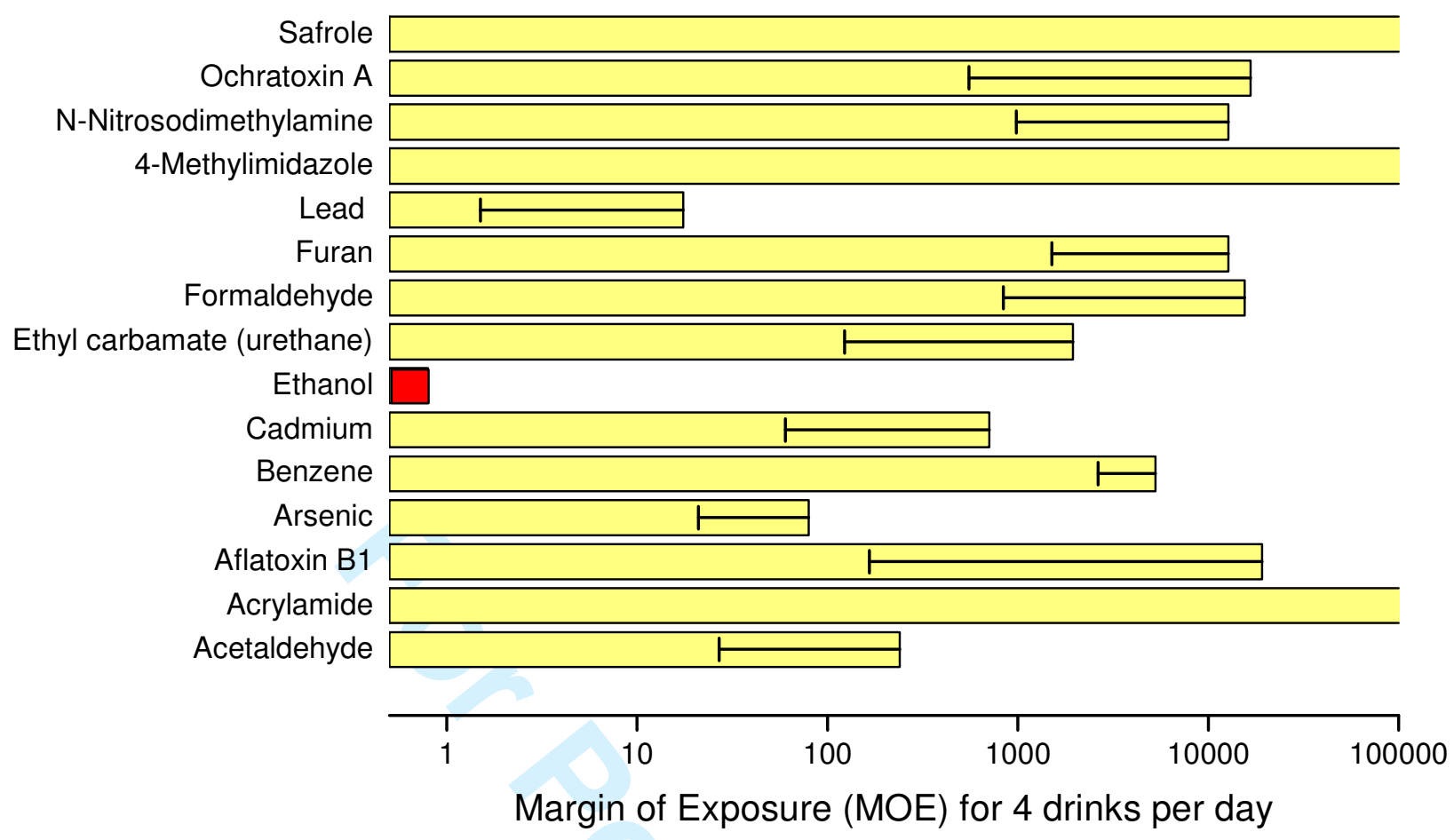

Figure 1. Margin of Exposure (MOE) for carcinogens occurring in alcoholic beverages for heavy drinking scenario (averages based on data from table 4; error bar indicates worst case contamination). 


\section{International Journal of Cancer}

Page 28 of 28

1
2
3
4
5
6
7
8
9
10
11
12
13
14
15
16
17
18

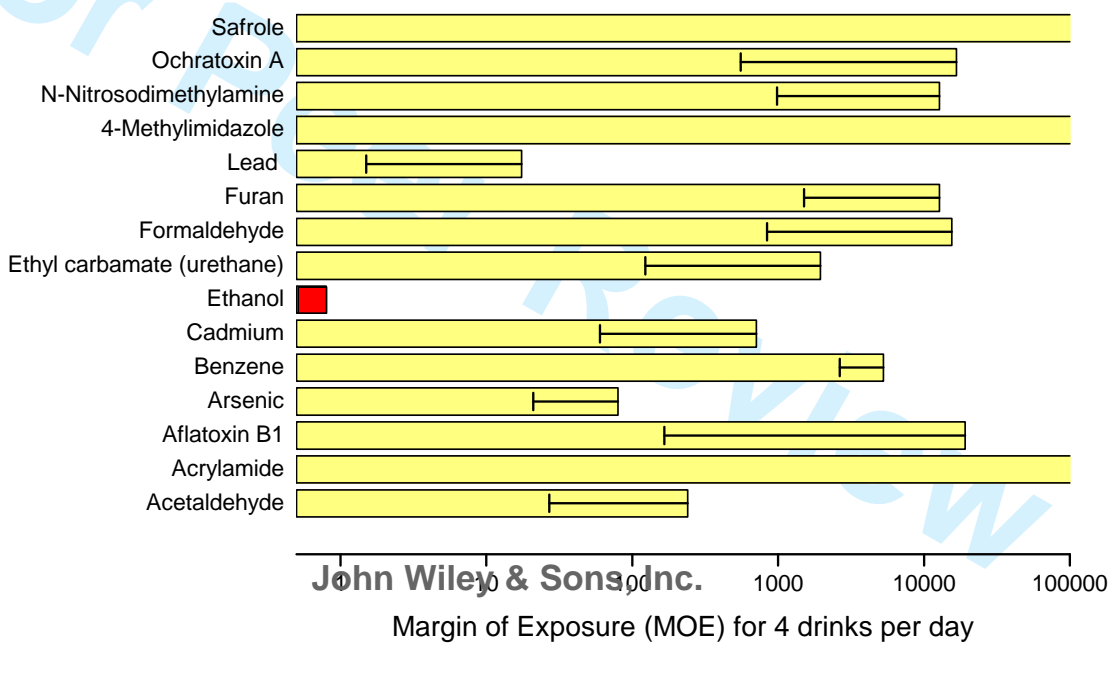

